\title{
POLITISASI ISU PRIBUMI PADA PEMILIHAN GUBERNUR DKI JAKARTA 2017 DI MEDIA SOSIAL
}

\author{
Tri Okta Putra Laksana ${ }^{1}$; Ridho Al-Hamidi²; Adibah Dhivani Gusmi ${ }^{3}$ \\ ${ }^{1,2,3}$ Program Studi Ilmu Pemerintahan Universitas Muhammadiyah Yogyakarta \\ e-mail: okalaksana79@gmail.com; ridhoalhamdi@umy.ac.id; adibah.dhivani.2013@ fisipol.umy.ac.id
}

\begin{abstract}
Abstrak: Artikel ini mengkaji tentang politisasi isu pribumi yang dilakukan oleh kubu Ahok dan Anies pada Pilgub Jakarta 2017 di media sosial (medsos). Politisasi diukur dengan tiga indikator: isu/ kepentingan, agenda politik, dan partisipasi. Secara metodologis, artikel ini merupakan hasil penelitian kualitatif dengan pendekatan studi kasus. Dalam pengumpulan data, facebook menjadi sumber utama untuk melihat prakter politisasi dari kedua kubu di medsos. Temuan penelitian ini menunjukkan tiga hal. Pada indikator pertama, kubu Ahok mengangkat isu Pilkada damai, Jakarta milik semua, dan keadilan untuk Ahok. Sementara kubu Anies menonjolkan isu pemimpin Muslim santun dan reklamasi pantai. Pada indikator kedua, kubu Ahok dan kubu Anies melakukan kampanye melalui konten yang menarik. Pada indikator ketiga, partisipasi yang dilakukan masyarakat adalah memberikan respon pada postingan akun medsos berupa like, share, dan komentar. Dari ketiga indikator terserbut, isu/kepentingan merupakan indikator paling dominan yang menyebabkan terjadinya politisasi isu pribumi pada Pilkada Jakarta 2017 di medsos.
\end{abstract}

Kata Kunci: Pribumi; Pemilihan Gubernur Jakarta 2017; Media sosial; Facebook

\begin{abstract}
This paper examines the politicization of indigenous issues both of Ahok and Anies factions in the 2017 Jakarta gubernatorial election on social media. The politicization is measured by a threefold indicator: issues/interests, political agenda, and participation. Methodologically, this paper uses qualitative research by applying case study. For data-gathering, Facebook is the primary source to investigate the politicization of both factions on social media. The finding demonstrates three things. First, Ahok faction offers the peaceful election, Jakarta belongs to all and the justice for Ahok. Meanwhile, Anis faction proposes the issues of Muslim leaders and reclamation. Second, both factions fight to campaign through social media to attract society's belief. Third, the participation conducted by society is responding to both factions' social media accounts with their like, share, and comments. Among those three indicators, the issue/interest is the dominant indicator causing the politicization of indigenous issues in the 2017 Jakarta Gubernatorial election on social media.
\end{abstract}

Keyword: Indigenous; 2017 Jakarta Gubernatorial Election; Social Media; Facebook

\section{PENDAHULUAN}

Indonesia merupakan negara yang terdiri dari banyak keanekaragaman suku, agama, ras dan golongan (SARA) yang menjadikan kekayaan budaya yang dimiliki Indonesia. Tetapi, dengan itu ada dampak negatif yang dapat menjadikan konflik antar budaya. Penyebab terjadinya konflik di Indonesia, seperti keberadaan non-pribumi versus pribumi, konflik agama, khususnya agama Islam dan agama Kristen dan isu kesukuan khususnya dominasi jawa dalam sejarah politik di Indonesia. Terjadinya konflik atas dasar isu-isu karena kesenjangan ekonomi politik yang terjadi seperti kekayaan non-pribumi atas pribumi, kekayaan minoritas Kristen atas mayoritas umat Islam, dan dominasi suku jawa atas non jawa dalam pentas politik. 
Terdapat banyak konflik permasalahan dalam hubungan etnik di Indonesia yang berujung kepada konflik, seperti isu pribumi (Indonesia asli) dengan non-pribumi (China keturunan), dan isu agama (Tajuddin \& Sani, 2016).

Istilah dari pribumi muncul pada masa kolonial Hindia Belanda dalam undang-undang Belanda tahun 1854 oleh pemerintahan Kolonial Belanda yaitu beragam kelompok penduduk asli di Nusantara sebagai bentuk diskriminasi sosial. Pada masa kolonial Belanda adanya segresi (pemisahan) rasial dalam tiga tingkat: ras kelas pertama adalah Europeanen (Eropa kulit putih), ras kelas kedua adalah Vreemde Oosterlingen (Timur asing) yang terdiri dari orang Tionghoa, Arab, India maupun non-eropa dan ras yang ketiga adalah Inlander, yang diterjemahkan yaitu "Pribumi" (kompas.com, 2017).

Adanya aturan yang mengatur orang-orang bangsa Indonesia asli dan orang-orang bangsa lain menurut Pasal 26 ayat (1) UUD 1945 konsekuensi dengan perincian dalam Pasal 1 huruf a dan Pasal 1 huruf b UU No.3 tahun 1946 tentang warga Negara dan Penduduk Negara RI. Pada penjelasan Pasal 26 ayat (1) UUD 1945 menggunakan contoh untuk orang-orang bangsa lain yang disahkan dengan undang-undang sebagai warga Negara dengan istilah "Peranakan", maka penjabaran siapa saja Warga Negara Indonesia dalam UU 1946 No.3 digunakan kriterium turunan yang memenuhi syarat-syarat dalam Undang-undang ini. selanjutnya bahasa seharihari untuk orang-orang bangsa Indonesia asli digunakan istilah "asli". Sedangkan untuk orangorang bangsa lain Pemerintahan menggunakan istilah "Warga Negara Turunan Asing" atau disingkat "TURSING" yang sangat disayangkan yaitu sampai dengan amandemen keempat UUD 1945 tidak diadakan perubahan pada Pasal 26 ayat (1) UUD 1945 dimana masih terdapat kata "Indonesia asli". Menyebabkan perlakuan diskriminatif terhadap etnis tertentu di Indonesia karena masih terdapatnya kalimat "warga negara adalah orang-orang bangsa Indonesia asli" maka hal ini merupakan pembenaran (legitimasi) atas tindakan diskriminasi pemerintah (negara) terhadap warga negaranya sendiri (Ngadino, 2009).

Permasalahan yang terjadi yaitu mengenai penduduk asli "mayoritas" dan pendatang "minoritas" sehingga adanya diskriminasi dari golongan mayoritas merasa akan lebih berkuasa dari pada golongan minoritas Sehingga membuat golongan minoritas akan merasa terkucilkan dalam lingkungannya. Melihat kondisi Jakarta yang merupakan daerah majemuk, perpecahan dapat dengan mudah terjadi pada daerah yang majemuk yaitu sangat rentan terjadi karena banyaknya perbedaan yang ada dan belum tentu setiap suku maupun etnis yang ada di Jakarta bisa paham dan saling mengerti dengan etnis lainnya. Pada penyelenggaraan Pilkada Jakarta 2017 isu agama, isu etnis juga turut mewarnai berjalannya proses tersebut, yang menyerang salah satu kandidat yaitu Ahok yang menjadi objeknya, yang menganut agama Kristen dan keturunan etnis China. Etnis China merupakan golongan minoritas di Jakarta secara golongan Ahok berasal dari golongan minoritas karena beragama Kristen dan keturunan etnis China. Menjadikan adanya gejolak politik identitas di pilkada tersebut, Maka adanya perbedaan antara etnik China dan pribumi menjadikan etnik China sulit untuk di terima sebagai bagian dari Indonesia (Sipahutar, 2018).

Politisasi Isu pribumi pada Pilgub Jakarta 2017 di gunakan untuk menjaring suara dimana isu yang digunakan untuk memilih kepala daerah yang berasal dari daerah asal atau pribumi. Adanya rasisme yang dilakukan terhadap kelompok etnis tertentu yang pada dasarnya 
karena alasan politik. Hal tersebut dapat mempengaruhi pemikiran masyarakat secara umum untuk membenci terhadap kelompok etnis tertentu, apalagi pada era saat ini penyebaran kebencian bisa berkembang lebih luas melalui media sosial (selanjutnya disingkat medsos). Dengan adanya medsos menjadikan segala bentuk informasi yang luas dan beragam dapat mempengaruhi pandangan masyarakat terhadap suatu peristiwa. Apalagi informasi yang disajikan tersebut dilakukan secara terus-menerus, secara tidak langsung pikiran masyarakat akan terpengaruhi dan menjadikannya opini masyarakat (geotimes.com, 2017).

Laporan Tetra Pak Index 2017 pengguna medsos meningkat yaitu pengguna internet di Indonesia diperkirakan 132 juta. Pengguna medsos yaitu berkisar 40\%. Dari data tersebut adanya peningkatan dibanding tahun 2016, meningkatnya pengguna internet di Indonesia sekitar 51\% atau 45 juta pengguna diikuti pertumbuhan yaitu sebesar $34 \%$ pengguna aktif medsos. Pada pengguna medsos yang mengakses melalui mobile berada di angka 39\%. Adanya lebih dari 106 juta orang Indonesia sebagai pengguna medsos tiap bulannya. Dengan 85\% di antaranya mengakses medsos melalui perangkat seluler (detik.com, 2017).

Habernas (dalam Ardha, 2014) semakin meningkatnya pengguna medsos dimanfaatkan oleh politisi, warga dan wartawan seperti Twiter, Facebook, dan Youtube sebagai bentuk untuk mendukung dari tujuan-tujuan dari politik mereka, sehingga nantinya mereka bisa terlibat dengan para pemangku kepentingan lainnya dalam ruang publik politik, kampanye, menyebarkan atau mengambil informasi dan berkontribusi terhadap perdebatan rasional kritis. Dengan menguasai komunikasi publik adalah salah satu kunci untuk bisa memenangkan kompetesi di dunia politik, saat ini salah satu chanel yang efektif adalah medsos.

Pengaruh medsos pada Pilkada Jakarta 2017 menurut survei yang dilakukan melalui medsos oleh Lembaga Survei Indonesia (LSI) pada 27 Februari-3 Maret 2017 dengan 440 responden, mayoritas pemilih di Jakarta yang aktif di medsos sebanyak 58,9\% dan 40,50\% tidak aktif di medsos. Dari pemilih yang aktif mengikuti perkembangan pilkada sampai hari tenang sebanyak $75,2 \%$, Sedangkan hanya $11,5 \%$ tidak aktif di hari tenang. Para pemilih tersebut aktif di tiga platform medsos, yaitu Facebook, Instagram dan Twitter. Untuk yang aktif di Facebook sebanyak 57,80 persen, Instagram sebanyak 29,30\% dan Twitter sebanyak $17,20 \%$ (detik.com, 2017).

Dengan memanfaatkan pengaruh dari medsos, Cagub dan Cawagub Jakarta 2017 memiliki akun resmi di medsos (detik.com, 2016). Paslon nomor urut satu, pasangan Agus Yudhoyono dan Sylviana Murni memiliki tiga akun medsos:
Facebook
: AgusSylfiForDKI1
Twitter
: @ AgusSylviDKI
Instagram
: @ AgusSylviForDKI1

Paslon nomor dua, Basuki T Purnama dan Djarot Saiful Hidayat juga menggunakan tiga akun medsos dan satu website resmi.

$\begin{array}{ll}\text { Facebook } & : \text { AhokDjarot } \\ \text { Twitter } & : \text { @ AhokDjarot } \\ \text { Instagram } & : \text { @ AhokDjarot } \\ \text { Website } & \text { : www.ahokdjarot.id. }\end{array}$


Paslon nomor tiga, Anis Baswedan dan Sandiaga Uno memiliki lebih banyak akun medsos dibanding kandidat lainnya.

$\begin{array}{ll}\text { Facebook } & \text { : AnisSandi } \\ & \text { SuaraAnies } \\ \text { Twitter } & : @ \text { jktmajubersama } \\ & \text { @ SuaraAnies } \\ \text { Instagram } & \text { : Jakartamajubersama } \\ & \text { SuaraAnies }\end{array}$

Akun medsos yang digunakan para Cagub-Cawagub digunakan sebagai strategi kampanye, penajaman visi-misi dan sosialisasi program. Karena medsos sebagai sarana paling efektif melihat pada jumlah pengguna aktif jejaring sosial. Pengaruh medsos memiliki peran penting untuk mengubah penilaian orang tentang suatu hal sehingga lebih efektif untuk menjaring pemilih (tempo.com, 2017). Pada pilkada Jakarta 2017 dengan para paslon memiliki akun medsos menimbulkan efek positif dan juga efek negatif dari medsos itu sendiri yaitu dengan adanya praktik hatespeech atau ujaran kebencian yang disebarkan yaitu melalui medsos, berita dan informasi mengenai ketiga paslon Cagub dan Cawagub Jakarta yang banyak diperbincangkan di media online oleh para pendukung maupun haters (pembenci) masingmasing. Pada penyelengaraaan Pilkada Jakarta 2017 sarat dengan ujaran kebencian yang dikembangkan masing-masing pendukung terhadap rival mereka.

\section{METODE PENELITIAN}

Paper ini merupakan hasil dari penelitian kualitatif yang bersifat kepustakaan (library research). Menurut Nazir (2003: 27), menyatakan bahwa studi kepustakaan adalah teknik pengumpulan data yang dilakukan dengan studi kajian terhadap buku-buku, literature, catatancatatan, dan laporan-laporan yang ada hubungannya dengan masalah yang ingin dipecahkan. Studi kepustakaan merupakan langkah penting dimana setelah menentukan topik penelitian, langkah selanjutnya yaitu pencairan teori dengan mengumpulkan informasi-informasi serta data yang berhubungan dengan topik penelitian. Kemudian, langkah selanjutnya yaitu melakukan kajian dan analisis mengenai teori yang sudah ditemukan..

Data primer dari penelitian ini bersumber dari berita online, media bereputasi, kredibel dan akun facebook antara kubu Ahok dan Anies. Data sekunder yang diperlukan dengan mengandalkan dokumen berupa jurnal-jurnal, dan buku yang sesuai dengan penelitian. Untuk teknik analisa dapat dilakukan dengan cara reduksi data, pembahasan dan pengambilan kesimpulan.

\section{HASIL DAN PEMBAHASAN}

Untuk mengukur politisasi isu pribumi yang dilakukan oleh kubu Ahok dan kubu Anis pada Pilgub Jakarta 2017 di medsos, penelitian ini menggunakan tiga indikator dalam teori Tournquist yang menjadi tolok ukur: isu dan kepentingan, agenda politik, dan partisipasi. 


\section{Isu dan Kepentingan}

Pada Pilkada yang diselenggarakan di Jakarta Tahun 2017 para Calon Gubernur dan Calon Wakil Gubernur menjadikan medsos sebagai alat untuk menyebarkan isu dan kepentingan yang berguna untuk Pilkada Jakarta 2017 yaitu berupa konsep dan gagasan. Isu yang digunakan pada Pilkada Jakarta yaitu untuk mempengaruhi masyarakat dalam hak pilihnya untuk menentukan pilihan dengan memanfaatkan akun medsos para pasangan calon bebas membuat dan menyebarkan isu berupa konten yang mereka posting di akun medsos yang bertujuan untuk mempengaruhi masyarakat pengguna medsos sehingga dengan itu dapat memenangkan Pilkada yang berlangsung di Jakarta pada tahun 2017. Adanya isu yang digunakan antara kubu Ahok dan Anies di akun resmi medsos merekapun beragam. Sehingga membuat masyarakat yang membaca akan terpengaruhi dengan isu yang telah dibuat dan disebarkan di akun medsos oleh kubu Ahok dan Anies.

Antara kubu Ahok dan Anies saling membuat dan menggunakan isu di akun medsos mereka untuk kepentingan politik mereka pada pagelaran pilkada di Jakarta 2017 untuk saling serang untuk mempengaruhi persepsi masyarakat sehingga nantinya dapat menjaring suara pemilih melalui isu di medsos. Di medsos penggunaan isu mengenai suku, agama, ras dan golongan dalam pilkada Jakarta 2017 yang paling banyak digunakan untuk saling serang oleh pendukung masing-masing antara kubu Ahok dan Anies sebagai alat untuk kepentingan Pilkada di Jakarta 2017. Di medsos sendiri orang-orang yang menggunakan isu-isu kebencian suku, agama, ras dan golongan hanya demi memenangkan calon yang didukung dengan adanya isu yang digunakan menyebabkan adanya masalah intoleransi antar masyarakat. Isu yang banyak disebarkan di medsos menjadikan dampak negatif bagi bangsa yang menganut keberagaman (tempo.com, 2016). Menurut survei yang dilakukan direktur Eksekutif Poltracking Indonesia Hanta Yudha menjelaskan bahwa beberapa faktor yang bisa mempengaruhi masyarakat untuk merubah pilihannya pada Pilkada Jakarta 2017. Pada survei menyatakan bahwa informasi yang berasal dari isu di medsos merupakan penyebab terbesar berubahnya pilihan seseorang kepada cagub-cawagub Jakarta 2017. Banyak pemilih yang terpengaruh isu di medsos yaitu 21,39 persen. Faktor penyebab lainnya yaitu pada penampilan cagub-cawagub pada pelaksanaan debat juga mempengaruhi pilihan masyarakat sebesar 16,8 persen. Selanjutnya yaitu pada visi dan misi, dan program kerja cagub serta pengaruh berita media dan pengaruh lingkungan yang menyebabkan seseorang mengubah pilihannya (kompas.com, 2017). Perlu kita ketahui yaitu mengenai frekuensi isu di akun medsos yang digunakan oleh kedua kubu antara Ahok dan Anies Facebook sebagai berikut:

\section{a. Frekuensi Isu Kubu Ahok dan Kubu Anies di Facebook}

Medsos berperan sangat penting sebagai informasi bagi publik. Pengaruh dari medsos dalam pengarahan isu publik semakin kuat. Hal ini terbukti dengan masifnya media konvensional dalam hal memanfaatkan medsos untuk distribusi pemberitaan. Seperti media televisi dan radio memberi ruang khusus dalam program mereka untuk mengulas isu terhangat yang sedang di perbincangkan di medsos. Dengan jejaring di medsos memungkinkan adanya pola pengarahan isu untuk menggiring opini publik. Hal itu, terjadi akibat perbedaan dominasi 
isu antara percakapan yang digerakan oleh publik dan isu yang digerakan pada medsos (Kompas, 2015).

Pada Pilkada yang berlangsung di jakarta 2017 yaitu antara kubu Ahok dan Anies menggunakan medsos untuk berkampanye menjadi bagian penting oleh tim sukses dari kedua kubu. Cagub-Cawagub tersebut menggunakannya untuk memposting kegiatan sehari-hari sebagai bentuk informasi untuk mempengaruhi pendukung dan masyarakat di medsos. Seperti pada kampanye dan sosialisasi yang dilakukan di medsos yaitu untuk menyasar kelompok masyarakat atau calon pemilih yang disebut generasi Z. Mereka adalah orang-orang yang sangat aktif di medsos. Jika kita melihat pada akun facebook yaitu: AhokDjarot dan SuaraAnies, mereka menggunakan facebook untuk memposting segala bentuk informasi sebagai kepentingan Pilkada Jakarta 2017 dalam bentuk kegiatan, kampanye, sosialisasi program, penajaman visi dan misi.

\section{Gambar 1. Akun Facebook Ahok dan Anies}

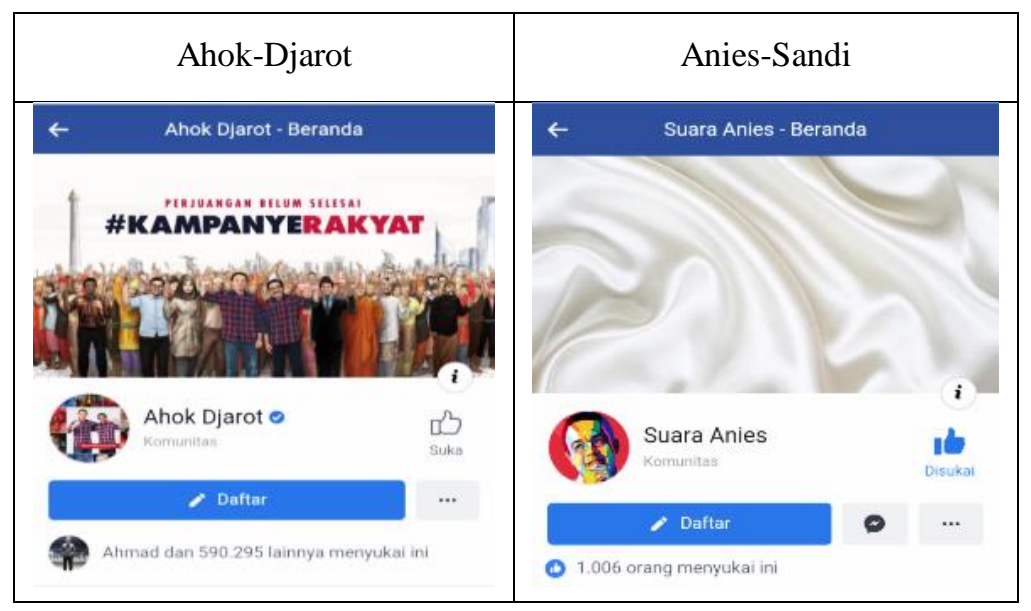

Sumber: Facebook AhokDjarot dan SuaraAnies

Berdasarkan akun medsos kedua kubu seperti terlihat pada Gambar 1, terdapat postingan konten yang terkait dengan isu yang digunakan oleh kedua kubu yang dibuat untuk mempengaruhi pandangan masyarakat yang kemudian disebarkan melalui akun medsos masing-masing. Adanya postingan kubu Ahok dan Anies yang dibuat yaitu berupa isu politik pada Pilkada 2017 di medsos yaitu melalui facebook. Kedua kubu menggunakan isu yang digunakan untuk kepentingan yang dapat mempengaruhi pilihan masyarakat sehingga dapat menjaring suara untuk memenangkan Pilkada Jakarta 2017. Frekuensi isu yang digunakan Ahok dan Anies di facebook dapat dilihat pada Tabel 1. 
Tabel 1. Frekuensi Isu Ahok dan Anies di Facebook

\begin{tabular}{|c|c|c|c|c|}
\hline No & Nama & Isu & Waktu & Frekuensi \\
\hline \multirow{14}{*}{1} & \multirow{13}{*}{ Ahok-Djarot } & \multirow{2}{*}{ Pikada Damai } & $10 / 2 / 2017$ & 2 \\
\hline & & & $11 / 2 / 2017$ & 6 \\
\hline & & \multirow{8}{*}{$\begin{array}{l}\text { Jakarta Punya Semua } \\
\text { (Keberagaman) }\end{array}$} & 20/3/2017 & 1 \\
\hline & & & $27 / 3 / 2017$ & 1 \\
\hline & & & $28 / 3 / 2017$ & 1 \\
\hline & & & $2 / 4 / 2017$ & 1 \\
\hline & & & $5 / 4 / 2017$ & 1 \\
\hline & & & $8 / 4 / 2017$ & 2 \\
\hline & & & $12 / 4 / 2017$ & 1 \\
\hline & & & $15 / 4 / 2017$ & 3 \\
\hline & & \multirow{3}{*}{ Keadilan Untuk Ahok } & $10 / 5 / 2017$ & 5 \\
\hline & & & $11 / 5 / 2017$ & 2 \\
\hline & & & $20 / 5 / 2017$ & 13 \\
\hline & Jumlah & 3 & 13 & 39 \\
\hline \multirow{16}{*}{2} & \multirow{16}{*}{ Anies-Sandi } & \multirow{15}{*}{ Pemimpin Muslim Santun } & $14 / 11 / 2016$ & 1 \\
\hline & & & $17 / 11 / 2016$ & 1 \\
\hline & & & 19/11/2016 & 1 \\
\hline & & & $5 / 12 / 2016$ & 1 \\
\hline & & & $12 / 12 / 2016$ & 1 \\
\hline & & & $15 / 12 / 2016$ & 1 \\
\hline & & & $16 / 12 / 2016$ & 1 \\
\hline & & & $6 / 12 / 2017$ & 1 \\
\hline & & & $8 / 1 / 2017$ & 1 \\
\hline & & & $10 / 1 / 2017$ & 1 \\
\hline & & & $23 / 1 / 2017$ & 12 \\
\hline & & & $27 / 1 / 2017$ & 1 \\
\hline & & & $10 / 2 / 2017$ & 1 \\
\hline & & & $16 / 2 / 2017$ & 1 \\
\hline & & & $12 / 3 / 2017$ & 1 \\
\hline & & Reklamasi Pantai & $24 / 1 / 2017$ & 3 \\
\hline & Jumlah & 2 & 16 & 18 \\
\hline
\end{tabular}

Sumber: Diolah oleh Penulis (2019)

Berdasarkan analisis mengenai frekuensi isu di akun facebook antara kedua kubu, facebook Ahok menawarkan tiga isu: Pilkada damai, Jakarta punya semua (keberagaman) dan keadilan untuk Ahok yang diunggah di facebook sebanyak 13 kali dan 39 kali postingan. Sementar akun facebook Anies mengawarkan dua isu: pemimpin Muslim santun dan reklamasi pantai yang diunggah sebanyak 16 kali dan 18 kali postingan.

\section{b. Isu Ahok-Djarot di Facebook}

\section{1) Pilkada Damai}

Pada pelaksanaan Pilkada yang berlangsung di Jakarta 2017 pasangan Ahok-Djarot menjadikan pilkada dengan menghadirkan persaingan sehat pada proses kontestasi Pilkada. Sehingga pada pelaksanaan Pilkada yang berlangsung di Jakarta 2017 dapat berjalan dengan damai, berintegritas dan demokratis. Dengan menggunakan Pilkada damai berharap kepada lawan politiknya pada saat pelaksanaan pilkada tidak menggunakan cara dengan 
menyebarkan isu-isu negatif seperti menggunakan ujaran kebencian terhadap Suku, Agama, Ras, dan Golongan tertentu.

Seperti pada postingan di akun facebook Ahok-Djarot dapat kita lihat berdasarkan pada postingan akun facebook pesan yang dibawa oleh kubu Ahok-Djarot yaitu dengan menjadikan Pilkada Jakarta 2017 dengan suasana damai. Pesan yang dibawa oleh kubu Ahok-Djarot dengan menjelaskan bagaimana semua aparat dibayar oleh uang rakyat kewajiban kami melayani dan bekerja hanya untuk rakyat sebagai sebagai pejabat Ahok menjelaskan telah disumpah semua golongan sama tugasnya untuk membantu masyarakat yaitu dengan maksud semua masyarakat dari golongan manapun berhak untuk mendapatkan pekerjaan yang terpenting menghasilkan sesuatu kerja yang nyata. Maka dengan itu, dengan tidak menjadikan perbedaan latar belakang dan golongan seseorang sebagai penghambat. Pasangan Ahok-Djarot juga mengajak lawan politinya dan masyarakat dengan tidak menggunakan isu-isu yang dapat memecah belah kondisi masyarakat Jakarta yaitu dengan tidak melakukan provokasi melalui isu negatif yang terkait dengan mempolitisasi isu pribumi yang ditujukan kepada Ahok sebagai golongan non pribumi di Jakarta yang berasal dari etnis China dan menganut agama Kristen. Karena dengan menggunakan isu kebencian terhadap suatu suku, agama, ras dan golongan dapat memecah belah dan menyebabkan konflik antar budaya didalam masyarakat. Maka dengan itu, pasangan calon Gubernur Ahok-Djarot ingin menghadirkan bahwa negara Pancasila hadir di Jakarta dengan keberagamannya.

Mereka juga ingin masyarakat Jakarta tidak mudah dipengaruhi oleh isu-isu yang disebarkan di medsos untuk menjatuhkan pasangan Ahok-Djarot. Maka dengan itu, kubu Ahok menjelaskan melalui postingannya seperti pilihlah pemimpin yang mampu kelola Ibu Kota Jakarta dengan bersih, transparan dan profesional yang terpenting memiliki hasil kerja nyata karena, banyaknya isu yang beredar untuk tidak memilih pemimpin yang bukan dari golongannya karena Indonesia merupakan Negara yang mayoritasnya Muslim. Kubu Ahok menjelaskan melalui postingannya sebagai pemimpin yang dapat dipercaya untuk memimpin Jakarta yaitu yang dibutuhkan kepalanya lurus, kalau kepalanya lurus pasti bawahnya pasti tidak berani tidak lurus dengan menggambarkan Ahok yang tidak pandang bulu sebagai pemimpin. Ahok-Djarot juga melalui facebooknya mejelaskan mengenai tidak hanya menjual program saja untuk para Cagub-Cawagub tetapi melaksanakannya seperti terlihat pada Gambar 2.

\section{Gambar 2. Postingan Ahok-Djarot di Facebook tentang Pilkada Damai}

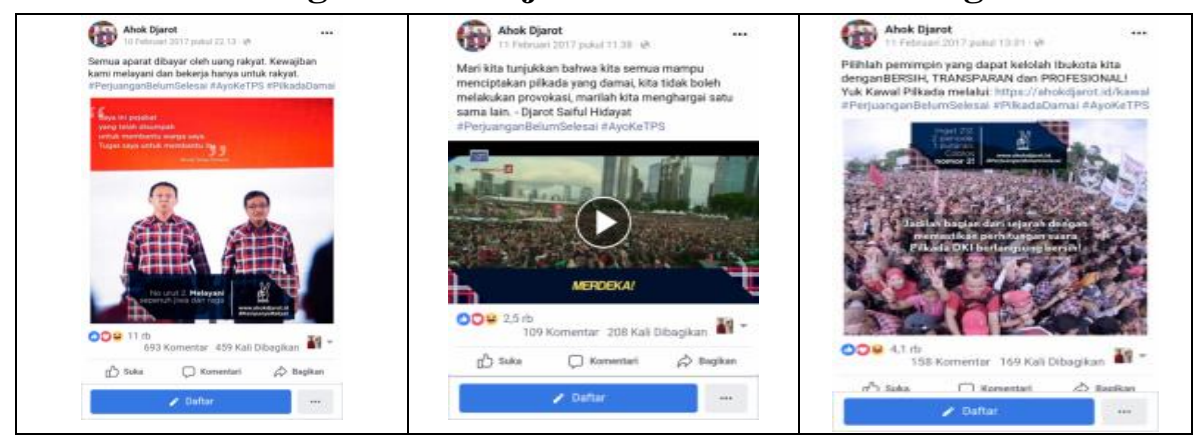




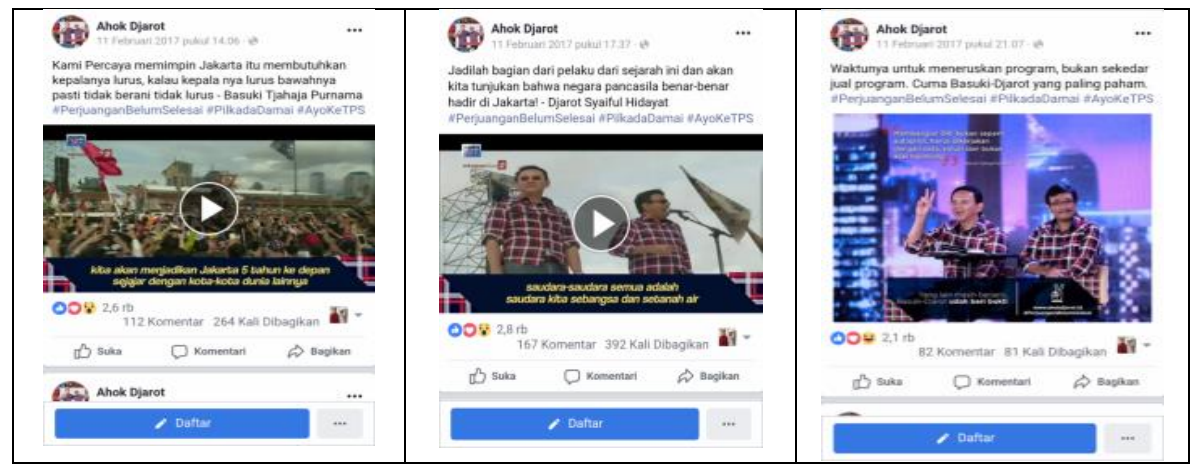

Sumber: https://m.facebook.com/AhokDjarot/

\section{2) Jakarta Punya Semua (Keberagaman)}

Negara Indonesia yang merupakan terdiri dari banyak keanekaragaman suku, agama, ras dan golongan yang menjadikan kekayaan Bangsa Indonesia. Tetapi, dengan itu ada dampak negatif yang menjadikan konflik antar budaya. Penyebab terjadinya konflik di Indonesia, seperti keberadaan pribumi versus non-pribumi. Hal itu, yang menjadikan peramasalahan isu yang terjadi pada pelaksanaan Pilkada yang berlangsung di Jakarta 2017 dengan menggunakan isu terkait dengan pribumi yang digunakan untuk menyerang latar belakang dari Ahok. Maka dengan itu, kubu Ahok-Djarot menggunakan isu di akun facebook yaitu dengan menggunakan isu mengenai Jakarta punya semua (keberagaman) agar masyarakat Jakarta tidak mudah terpengaruhi dengan isu-isu negatif yaitu mengenai isu pribumi yang digunakan oleh lawan politiknya untuk mempengaruhi persepsi masyarakat.

Mengenai politisasi isu pribumi merupakan isu yang digunakan oleh lawan politiknyan untuk menjatuhkan kredibilitas pasangan nomor urut dua selama Pilkada berlangsung di Jakarta 2017 yang digunakan sebagai alat untuk menyerang Ahok yang sebagai penganut agama kristen dan berasal dari keturunan etnis China. Isu tersebut di medsos digunakan untuk mengeksploitasi terkait dengan isu suku dan agama yang bertujuan untuk mempengaruhi masyarakat di medsos. Maka untuk mengatasi isu yang menyerang pasangan Ahok-Djarot, mereka menggunakan cara dengan menggunakan isu mengenai keberagaman untuk menggambarkan Jakarta.

\section{Gambar 3. Postingan Ahok-Djarot di Facebook tentang Jakarta Punya Semua (Keberagaman)}

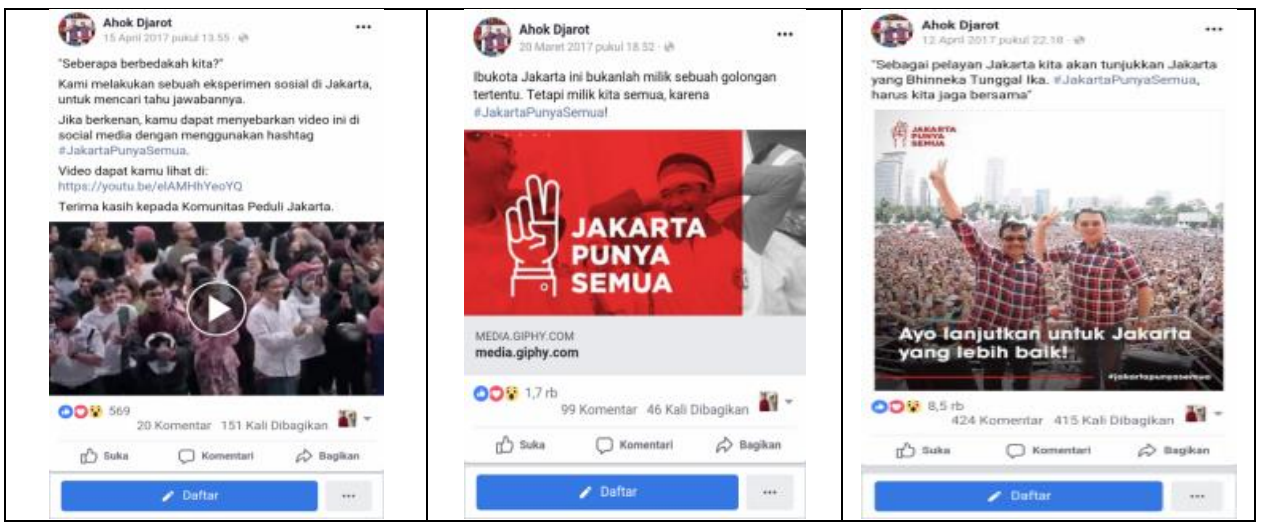




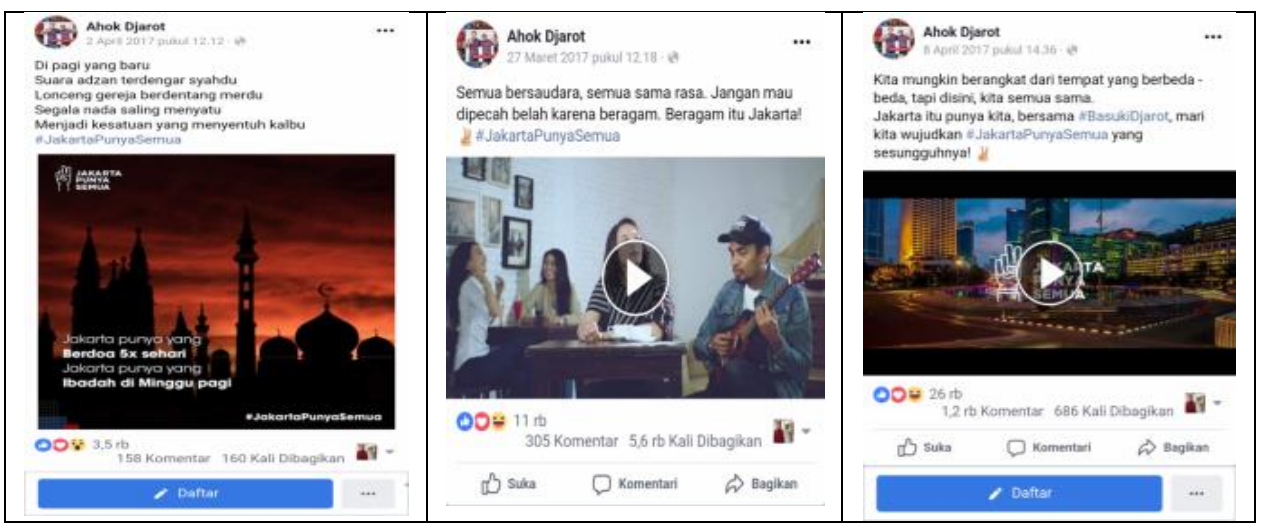

Sumber: https://m.facebook.com/AhokDjarot/

Isu Jakarta punya semua di akun facebook kubu Ahok-Djarot seperti di Gambar 3 menjelaskan tentang Indonesia yang memiliki kemajemukan, pluralitas, keberagaman suku, agama, ras dan golongan yang berdasarkan atas Bhineka Tunggal Ika. Kubu Ahok-Djarot menggunakan isu yang terkait dengan keberagaman karena adanya isu negatif yang menyerang Ahok yaitu dengan cara mempolitisasi latar belakang Ahok yang menganut agama Kristen dan keturunan etnis China yang merupakan golongan minoritas di Jakarta. Sedangkan Djarot menganut agama Islam dan berasal dari etnis jawa. Tim sukses AhokDjarot mengusung Keberagaman untuk menciptakan toleransi di masyarakat sehingga dengan hal itu, tidak menimbulkan permusuhan antar masyarakat yang disebabkan oleh perbedaan latar belakang seseorang yang berkaitan dengan SARA.

Perbedaan yang menjadikan keberagaman di dalam masyarakat yang di usung oleh kubu Ahok-Djarot dengan menggunakan simbol kebhinekaan yaitu semua suku, agama, ras dan golongan yang hidup menjadi satu di Indonesia. Dengan menggunakan isu "Jakarta Punya Semua (keberagaman)" yang digunakan oleh kubu Ahok-Djarot dengan menciptakan Ibu Kota Jakarta sebagai kota yang berdasarkan atas "Bhineka Tunggal Ika" yang berbedabeda tetapi tetap satu bukan hanya milik golongan tertentu saja. Dengan pengaruh isu tersebut, Ahok-Djarot mencoba untuk mempengaruhi pandangan masyarakat melalui facebook dengan memposting mengenai isu "Jakarta punya semua". Hal tersebut diharapkan mampu menyejukan masyarakat Jakarta.

\section{3) Keadilan untuk Ahok}

Pada Pilkada Jakarta 2017 adanya isu yang digunakan mengenai sentimen SARA yang sejak awal menyerang Ahok. Belum lagi adanya kasus yang menimpa Ahok yang terduga adanya penistaan agama yang dilakukan membuat elektabilitas dari Ahok menurun. Hal itu, berawal dari pidato Ahok di kepulauan seribu yang mengutip dari surat Al-Maidah ayat 51 yang kemudian potongan pidatonya itu di unggah ke facebook oleh Buni Yani dan menjadikannya viral di medsos. Unggahan vidio tersebut dimanfaatkan oleh lawan politiknya untuk menyerang kubu Ahok, pasca pidatonya berbagai elemen masyarakat yang didominasi oleh ormas-ormas Islam termasuk FPI yang sejak awal sangat anti Ahok melakukan aksi yang tujuannya untuk memenjarakan Ahok karena dianggap telah menistakan agama. Sejak saat itulah, munculnya fatwa MUI yang menyuarakan haram 
untuk memilih pemimpin kafir (non-muslim). Pada kasus penistaan agama yang menimpa Ahok menjadikannya divonis hukuman dua tahun penjara.

Seperti pada postingan di akun facebook pada Gambar 4, Ahok-Djarot mengajak pendukung dan masyarakat untuk bersimpati terhadap kasus yang menimpa Ahok sehingga dalam menjalani kasusnya pemerintah untuk bersikap adil yaitu terkait dengan adanya kasus penistaan agama yang menimpa Ahok sehingga divonis dua tahun penjara. Maka dengan itu melalui facebook ahok memposting untuk mengajak pendukung dan masyarakat untuk peduli terhadap Ahok dengan melakukan aksi solidaritas atas matinya keadilan yaitu untuk mengajak masyarakat hadir di Tugu Proklamasi pada tanggal 10 Mei 2017.

\section{Gambar 4. Postingan Ahok-Djarot di Facebook tentang Keadilan untuk Ahok}

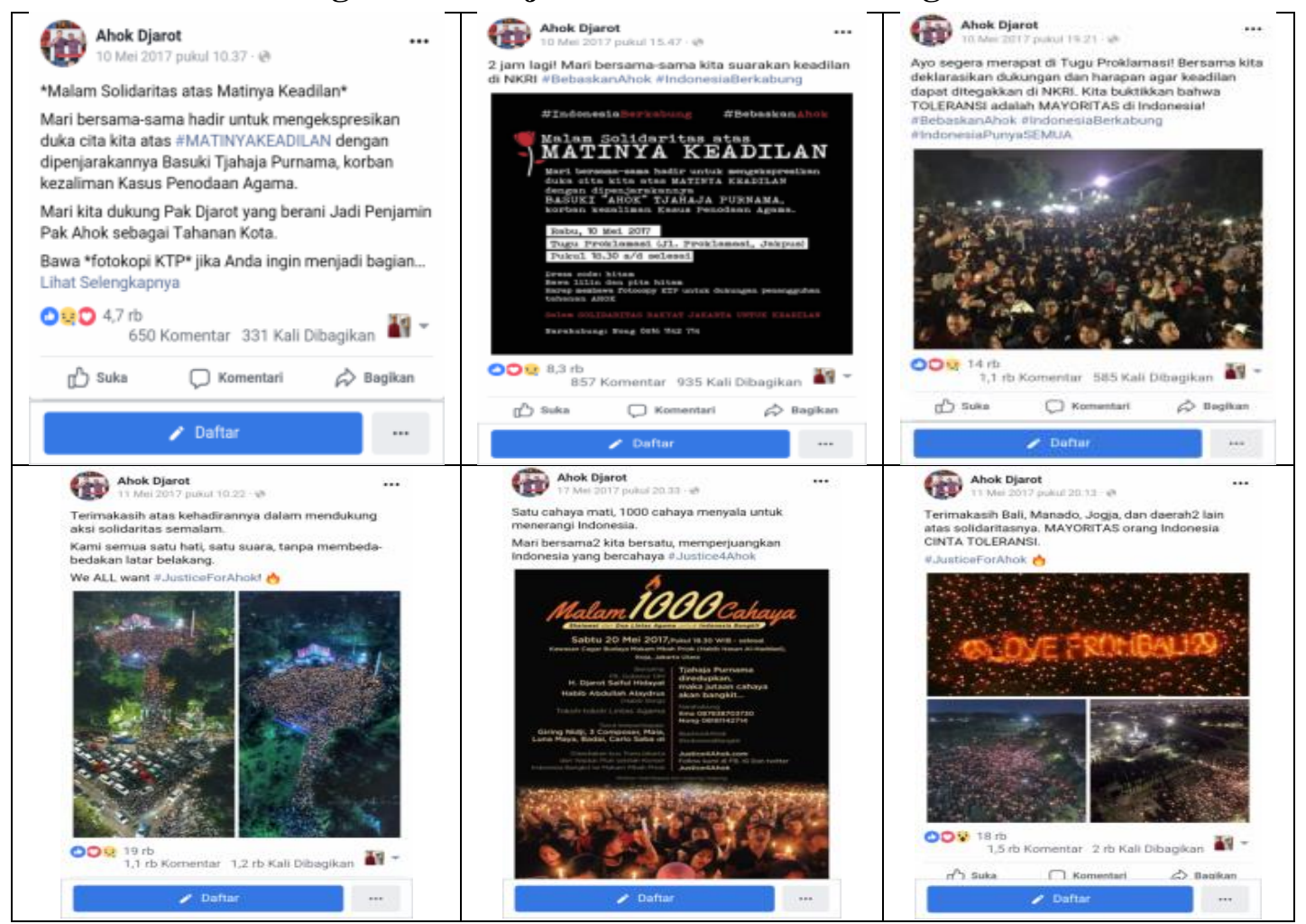

Sumber: https://m.facebook.com/AhokDjarot/

Puncaknya pada kasus yang menimpa Ahok yaitu adanya aksi tersebut dilakukan untuk membela Ahok agar lepas dari kasus dan jeratan hukum yang menimpanya. Dengan itu, kubu Ahok mengajak masyarakat untuk melawan atas ketidakadilan kasus yang menimpa Ahok karena dengan adanya aksi tersebut diharapkan masyarakat akan bersimpati dan pihak hukum bersikap adil atas kasus yang menimpa Ahok. Kubu Ahok-Djarot mengajak bagaimana untuk melakukan sikap saling toleransi antar umat beragama dan tidak menjadikan suatu konflik yang disebabkan isu dari latar belakang seseorang yaitu mengenai isu pribumi yang berkaitan dengan SARA yang digunakan lawan politiknya sebagai kepentingan untuk menjatuhkan Ahok pada Pilkada Jakarta 2017. 


\section{c. Isu Kubu Anies-Sandi di Facebook}

\section{1) Pemimpin Muslim Santun}

Sosok pemimpin Muslim santun digunakan untuk mempresentasikan pasangan AniesSandi pada Pilkada Jakarta 2017 seperti terlihat pada Gambar 5. Menggunakan latar belakang identitas sebagai orang pribumi dari golongan mayoritas serta beragama Islam pada Pilkada Jakarta tahun 2017 adalah mendapatkan dukungan masyarakat Jakarta.

\section{Gambar 5. Postingan Anies-Sandi di Facebook tentang Pemimpin Muslim Santun}

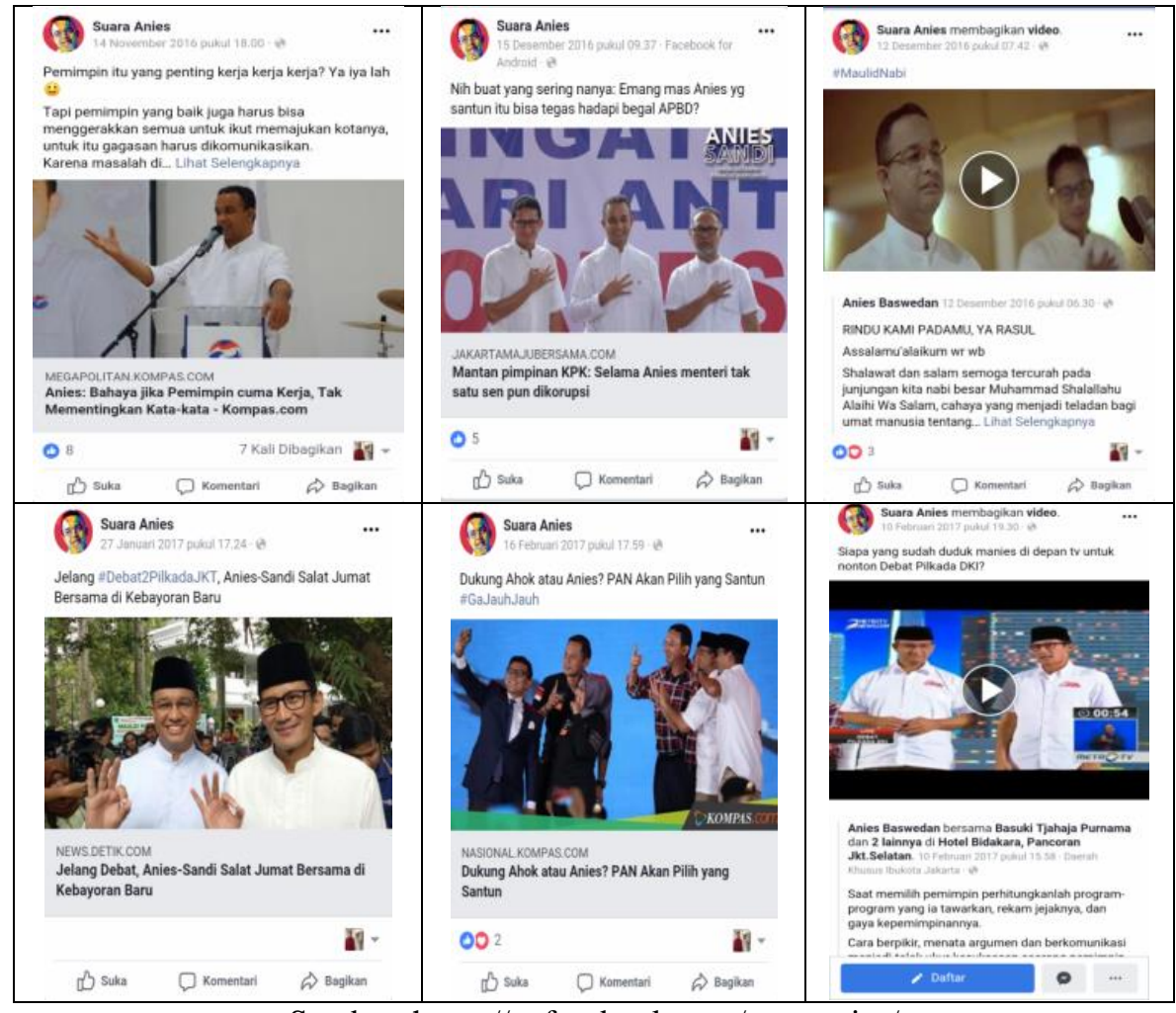

Sumber: https://m.facebook.com/suaraanies/

Sebagai lawan politiknya Ahok yang merupakan dari golongan minoritas berasal dari etnis China dan beragama Kristen. Memiliki karakter kepribadian dengan sikap yang tegas, berani dan gaya berbicara keras. Hal itu yang dimanfaatkan oleh Kubu Anies-Sandi dengan mempengaruhi masyarakat pada postingan facebook Anies-Sandi menggambarkan identitas yaitu pribadi muslim yang santun. Menjelaskan bahwa seorang pemimpin bukan hanya mengenai kerja, kerja, kerja tetapi harus memiliki kepribadian yang baik dan sopan sehingga bisa di contoh oleh masyarakatnya. Melalui postingan video pasangan Anies-Sandi bersholawat dan disertai teks yang menjelaskan seseorang harus mencontoh Nabi Muhammad SAW yang memiliki akhlak dan kepribadian baik yang merupakan suri tauladan umat muslim. Anies-Sandi juga menjelaskan saat memilih pemimpin perhitungkanlah program-program yang ditawarkan, rekam jejaknya dan gaya kepemimpinannya. Cara berpikir, menata argumen dan berkomunikasi. Hal itulah yang digunakan oleh kubu Anies untuk mendapatkan dukungan masyarakat pada Pilkada yang berlangsung di Jakarta 2017. 


\section{2) Reklamasi Pantai}

Pembangunan proyek reklamasi pantai yang berada di Jakarta memang sudah mulai direncanakan pada zaman Presiden Soeharto. Pada masa Ahok, dia menuangkannya pada SK Gubernur No. 2238 Tahun 2014 tentang pelaksana reklamasi. Pada pemilihan Pilkada yang berlangsung di Jakarta pada tahun 2017 yang juga Ahok sebagai gubernur petahana sebagai etnis China. Adanya diskusi yang dilakukan yaitu terkait dengan "Stop Proyek Reklamsi teluk jakarta. menurut ketua dewan kehormatan PAN Amien Rais mengatakan yaitu terkait beredar adanya isu reklamasi pantai di Jakarta yang nantinya bakal digunakan untuk kepentingan asing. Dengan 17 pulau reklamasi tersebut dijadikan pangkalan bagi etnis asing dan 17 pulau tersebut nantinya dipersembahkan untuk China, untuk kepentingan politik, ekonomi dan militer (merdeka.com, 2017). Sebagai pihak yang juga menentang pembangunan reklamasi pantai yaitu kubu Anies-Sandi mereka berjanji akan memberhentikan reklamasi pantai tersebut bila terpilih menjadi gubernur Jakarta 2017. Hal tersebut, menjadikan daya tarik bagi masyarakat Jakarta.

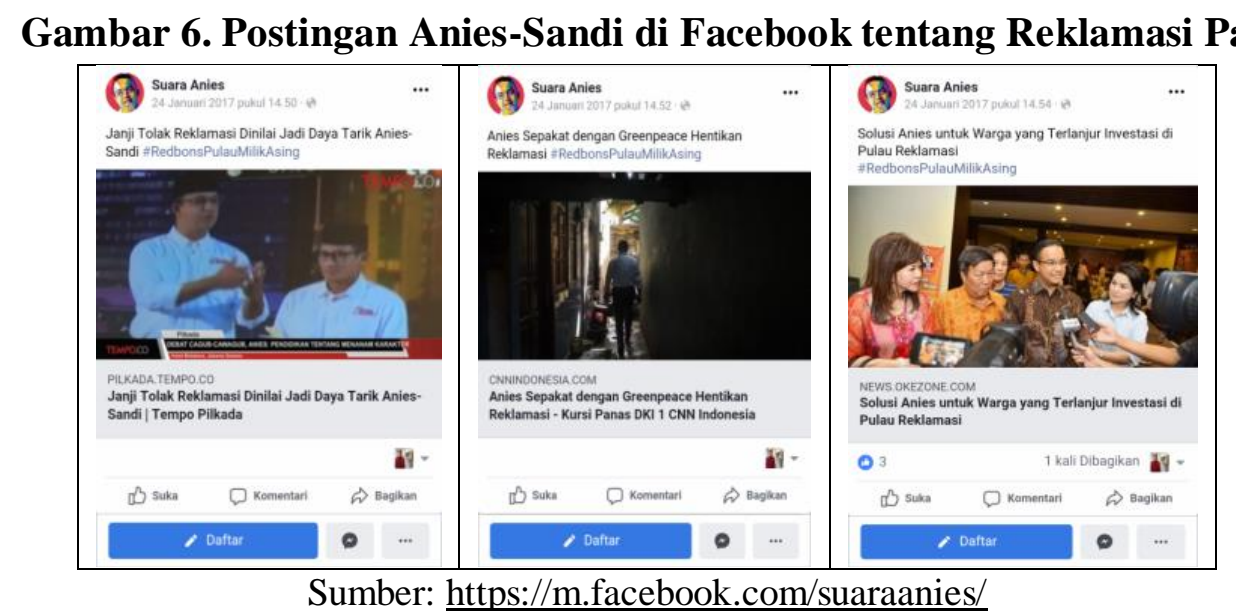

Dapat dilihat di Gambar 6, berdasarkan postingan facebook Anies-Sandi pada proyek reklamasi pantai yang dilakukan di Jakarta, Anies sebelumnya berjanji ketika dia menjadi gubernur Jakarta akan memberhentikan proyek reklamasi pantai tersebut yang dianggap nantinya digunakan untuk kepentingan asing dan reklamasi pantai dapat mengakibatkan merusak lingkungan. Terkait pada postingan pada facebook membahas isu mengenai reklamasi pantai yang berada di Jakarta yang akan diberhentikan proses pengerjaannya nanti pada saat kepemimpinannya. Dengan isu reklmasi pantai yang dibuat untuk kepentingan asing karena masyarakat kelas menengah kebawah tidak mungkin untuk membeli rumah di proyek reklamasi pantai tersebut dan para nelayan sekitar pantai akan dirugikan karena harus menempuh jarak jauh untuk mendapatkan ikan karena dampak dari reklamasi pantai yang diakibatkan oleh karena itu masyarakat banyak yang tidak setuju karena tidak merasakan manfaat dari proyek reklamasi pantai yang hanya merugikan dan dapat mengakibatkan dampak kerusakan lingkungan karena harus menimbun pantai dan juga merusak terumbu karang. Maka dengan memberhentikan proyek reklamasi pantai 
merupakan daya tarik dari pasangan kubu Anies-Sandi banyak masyarakat yang mendukung kebijakan Anies-Sandi untuk memberhentikan proyek reklamasi pantai.

Banyaknya pro dan kontra atas keputusan yang dibuat Anies terkait dengan proyek reklamasi pantai dan masyarakat yang kontra tidak percaya terutama terhadap keputusannya untuk memberhentikan proyek reklamasi pantai di Jakarta. Dan ketika Anies-Sandi menjadi Gubernur Jakarta terkait dengan pemberhentian proyek reklamasi pantai pada tanggal 26 September 2018 dia menepati janjinya dan berhasil menghentikan dengan mencabut izin terkait pembangunan reklamasi pantai di Jakarta dan berhasil merealisasikan janjinya yaitu berdasarkan badan koordinasi pengelolaan Reklamasi Pantai Utara jakarta yang dibentuk melalui Peraturan Gubernur Nomor 58 Tahun 2018 pada 4 Juni 2018.

\section{Agenda Politik}

Agenda politik merupakan dari serangkaian isu-isu yang diberitakan, digambarkan sehingga menjadikan pemberitaan mempunyai nilai lebih terhadap pada suatu persoalan yang muncul sehingga menjadikannya sebagai informasi bagi publik. Agenda politik biasanya berupa opini dalam berita-berita propaganda dan kampanye digunakan untuk dapat mempengaruhi publik sehingga mendapatkan keuntungan kepada suatu golongan atau kelompok tertentu. Pada agenda politik yang dilakukan saat berlangsungnya Pilkada di jakarta 2017 oleh para pasangan calon terdapat dua cara yang dilakukan antara kubu Ahok dan Anies sebagai berikut:

\section{a. Memberitakan Isu Melalui Opini Berita}

Media massa saat ini berfungsi sebagai alat untuk menyampaikan informasi, edukasi, hiburan dan mobilisasi. Media massa juga bisa digunakan untuk menyampaikan pesan, ide-ide, dan gagasan. Seperti gagasan keberagaman, Indonesia merupakan negara yang terdiri dan keanekaragamn suku, agama, ras dan golongan (SARA). Kebebasan media massa untuk memberitakan melalui opini berita yaitu ketika dimulainnya era reformasi termasuk media online (media daring) adanya kebebasan pers untuk kebebasan mengekpresikan gagasan dan mengkritik tajam lawan yang menentang gagasan (Junaidi, 2017). Pada pilkada yang berlangsung di Jakarta 2017 pengunaan istilah yang bernuansa isu pribumi, penulis melakukan penelitian terhadap berita-berita yang dimuat pada media online. Ketiga media itu adalah Detik.com, Merdeka.com, Kompas.com.

Berita-berita tersebut akan dikelompokan dengan menurut kategori sederhana yang bersifat netral yakni tidak mendukung dan menolak adanya isu SARA, positif, negatif dan netral dalam kaitannya dengan Isu Sara pada Pilkada. Penggolongan berita netral, positif negatif ini didasarkan pada judul-judul dan paragraf pertama atau teras berita (lead) yang digunakan dalam berita tersebut. Judul dan paragraf pertama dalam sebuah berita sudah dapat dipakai untuk menggambarkan isi dan pesan berita. Selanjutnya penulis akan menganalisis faktor-faktor apa saja yang mempengaruhi berita itu menjadi positif, negative dan netral.

Untuk membatasi waktu dan jumlahnya, berita diambil pada saat kampanye resmi putaran pertama dan kedua Pilkada: 26 Oktober 2016 hingga 15 April 2017. Beberapa kata kunci digunakan untuk memudahkan mencari berita-berita pada mesin pencarian seperti "Pilkada DKI Jakarta 2017" dan "SARA". 
Tabel 2. Berita di Media Daring

\begin{tabular}{|c|c|c|c|c|}
\hline No & Nama Media & Tanggal & Judul dan Teras Berita & Sifat \\
\hline \multirow[b]{2}{*}{1.} & \multirow[b]{2}{*}{ detik.com } & $5 / 4 / 2017$ & $\begin{array}{l}\text { Judul: Tim Anies : Kami Tak } \\
\text { Main Isu Sara Fokus pada } \\
\text { Program } \\
\text { Teras Berita: Beredar } \\
\text { spanduk bertulisan warga } \\
\text { Jakarta sudah bosan dengan } \\
\text { isu SARA di sejumlah titik di } \\
\text { Jakarta. Timses Anies-Sandi } \\
\text { menegaskan tak pernah } \\
\text { memainkan isu SARA di } \\
\text { tengah isu panas Pilgub. }\end{array}$ & Positif \\
\hline & & $5 / 4 / 2017$ & $\begin{array}{l}\text { Judul: Ada Spanduk Warga } \\
\text { Bosan Isu SARA, Ahok: } \\
\text { Tanya yang Pasang } \\
\text { Teras Berita: Sejumlah } \\
\text { spanduk bertulisan 'warga } \\
\text { Jakarta Bosan Isu SARA' } \\
\text { beredar di beberapa titik } \\
\text { Jakarta, Beredar sejak selasa } \\
\text { malam atau tepat dua pekan } \\
\text { menjelang digelarnya } \\
\text { pemungutan suara Pilkada } \\
\text { Jakarta } 2017 \text { pada } 19 \text { April } \\
\text { mendatang. }\end{array}$ & Netral \\
\hline \multirow[b]{2}{*}{2.} & \multirow[b]{2}{*}{ merdeka.com } & $10 / 3 / 2017$ & $\begin{array}{l}\text { Judul: Tudingan Keras Ruhut } \\
\text { ke Anies-Sandi Kerap } \\
\text { Bermain SARA di Pilgub } \\
\text { Teras Berita: Putaran dua } \\
\text { Pilgub mulai memanas sejak } \\
\text { kampanye resmi dibuka KPU } \\
\text { pada selasa (7/3) kemarin. } \\
\text { Sindiran pedas kian kental } \\
\text { terasa dilakukan dua kandidat } \\
\text { Gubernur dan Wakil gubernur } \\
\text { maupun tim sukses antar } \\
\text { masing-masing pasangan. }\end{array}$ & Negative \\
\hline & & $13 / 3 / 2017$ & $\begin{array}{l}\text { Judul: Anies Minta Pilgub } \\
\text { Tak Ada Ancaman-ancaman } \\
\text { dan Isu SARA } \\
\text { Teras Berita: Calon } \\
\text { Gubernur Jakarta Anies } \\
\text { menilai kasus almarhum } \\
\text { NenekHindun tak } \\
\text { dicampurkanadukkan dengan } \\
\text { masalah politik. Sebab Anies } \\
\text { menginginkan Pilgub Jakarta } \\
\text { ini berjalan dengan damai } \\
\text { bukan denganancaman- } \\
\text { ancaman. }\end{array}$ & Positif \\
\hline
\end{tabular}




\begin{tabular}{|c|c|c|c|c|}
\hline 3. & kompas.com & $28 / 10 / 2016$ & $\begin{array}{l}\text { Judul: Jelang Pilkada 2017, } \\
\text { hanya Jakarta yang Paling } \\
\text { Rawan Isu SARA } \\
\text { Teras Berita: Ketua Badan } \\
\text { Pengawas Pemilu (Bawaslu) } \\
\text { Muhammad mengatakan, } \\
\text { Jakarta menjadi daerah paling } \\
\text { rawan konflik yang dipicu isu } \\
\text { suku, agama, ras dan } \\
\text { antargolongan (SARA) } \\
\text { padaPilkada 2017. }\end{array}$ & Netral \\
\hline & & $18 / 2 / 2017$ & $\begin{array}{l}\text { Judul: Hanya Isu SARA yang } \\
\text { Dapat Menjegal Ahok-Djarot } \\
\text { pada Putaran Kedua } \\
\text { Teras Berita: Berdasarkan } \\
\text { rekapitulasi real count } \\
\text { dokumen C1 oleh KPU } \\
\text { Jakarta, pasangan Ahok- } \\
\text { Djarot memperoleh suara } \\
\text { terbanyak yakni } 2.357 .587 \\
\text { suara atau } 42,91 \text { persen. }\end{array}$ & Positif \\
\hline
\end{tabular}

Sumber : Diolah oleh Penulis (2019)

Sebagian berita-berita yang ada pada Tabel 2 menunjukan, bahwa berita-berita positif dalam pengertian ini tidak menggunakan isu SARA untuk kepentinngan Pilkada Jakarta 2017 lebih banyak dibandingkan berita-berita yang mendukung pengunaan Isu SARA pada Pilkada Jakarta 2017.

\section{b. Cara Memberitakan Melalui Kampanye di Medsos}

Kampanye melalui facebook dilakukan baik oleh Ahok-Djarot dan Anies-Sandi. Pada putaran kedua, KPU Jakarta mewajibkan kedua kubu berkampanye melalui medsos karena dirasa lebih efektif ketimbang baliho dan spanduk. Karena itu, tim sukses Ahok dan Anies berkampanye dengan memberitakan segala bentuk informasi yang mereka sebarkan di facebook untuk mendukung kampanye sebagai sarana adu gagasan dengan membuat konten yang menarik sehingga dapat mempengaruhi masyarakat pengguna medsos yaitu melalui facebook kubu Ahok dan Anies. Adapun kampanye di akun facebook yang dilakukan kedua calon sebagai berikut:

\section{1) Ahok-Djarot}

Kampanye yang dilakukan tim sukses Ahok-Djarot di facebook adalah dengan memposting teks, video, foto yang membuat menarik masyarakat pengguna. Melalui kampanye di facebook, kubu Ahok-Djarot juga memberikan pesan-pesan agar mempengaruhi masyarakat Jakarta untuk memilih pasangan mereka. 


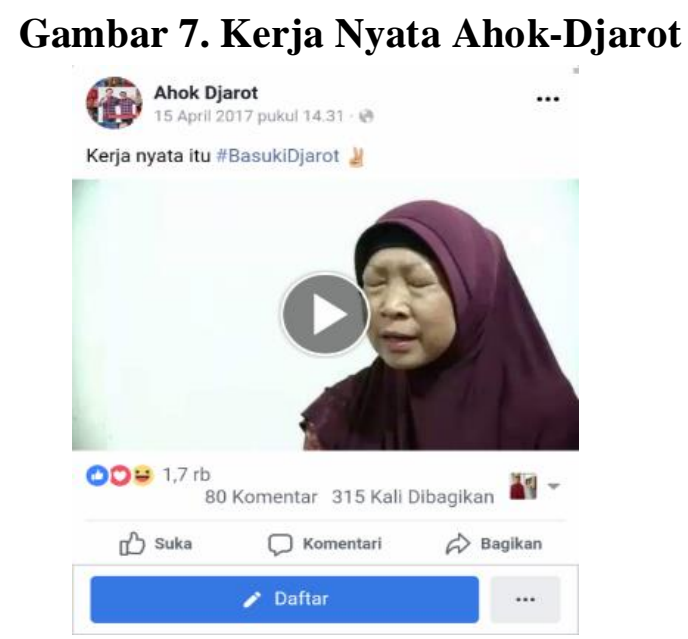

Sumber: https://m.facebook.com/AhokDjarot/

Gambar 7 menerangkan, bahwa seorang warga Jakarta bernama Yanti menjelaskan tentang kepemimpinan Ahok yang telah bekerja nyata meskipun dihantam dengan berbagai macam isu serta tidak menjadikan Ahok takut dan mundur. Mengenai gaya kepemimpinan Ahok yang membawa dan mengarahkan rakyat dengan benar melalui program-programnya. Yanti juga menjelaskan bahwa Gubernur Ahok merupakan seorang yang peduli dengan memperhatikan rakyatnya yaitu langsung turun ke jalan untuk mendengarkan keluhan masyarakat dan melihat langsung kondisi masyarakat. Yanti sangat yakin kepada Ahok dan menilai Ahok sebagai seorang yang jujur, ikhlas untuk membenahi Ibu Kota Jakarta serta meragukan kepemimpinan cagub lainnya.

\section{Gambar 8. 60 Detik buat Kamu yang Masih Bingung}

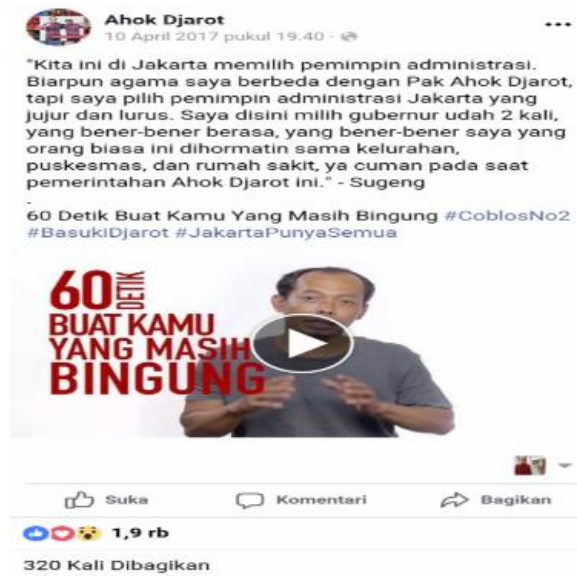

Sumber: https://m.facebook.com/AhokDjarot/

Gambar 8 menjelaskan tentang pesan singkat selama 60 detik untuk masyarakat yang masih bingung yang mana di dalam video tersebut, Sugeng yang bekerja sebagai karyawan menjelaskan opininya mengenai sosok pemimpin yang di cari di Jakarta yaitu sosok pemimpin administrasi yang bisa mengelola Jakarta. Sugeng juga menjelaskan bahwa sosok pemimpin bukan hanya dipilih berdasarkan kesamaan agamanya karena belum tentu agamanya sama seorang pemimpin bisa berlaku jujur dan adil. Sugeng juga menjelaskan 
walapun keyakinan agamanya beda dengan Ahok, dia merasa lebih dihormati sebagai rakyat kecil oleh pemerintah pada kepemimpinan Ahok-Djarot.

\section{Gambar 9. Perjuangan Belum Selesai}

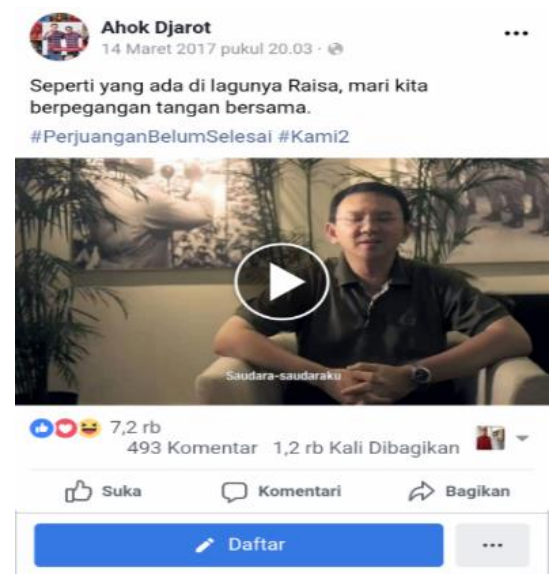

Sumber: https://m.facebook.com/AhokDjarot/

Gambar 9 menjelaskan tentang pesan Ahok yang mengajak pendukung dan masyarakat untuk saling berpegangtangan dan berjuang bersama dengan tidak takut terhadap rintangan apapun yang bertujuan untuk menjatuhkan pasangan Ahok-Djarot dengan isu-isu yang beredar di masyarakat. Maka dengan itu, karena perjuangan belum selesai, Ahok mengajak masyarakat Jakarta untuk saling berpegangan tangan bersama dan berjuang bersama demi untuk memenangkan Pilkada di Jakarta 2017 sehingga Ahok dapat terpilih sebagai gubernur Jakarta karena perjuangan mulia Ahok-Djarot yaitu untuk membangun Ibu Kota Jakarta sebagai kota yang maju dengan keikhlasan dan ketulusan juga melalui doa kepada Tuhan.

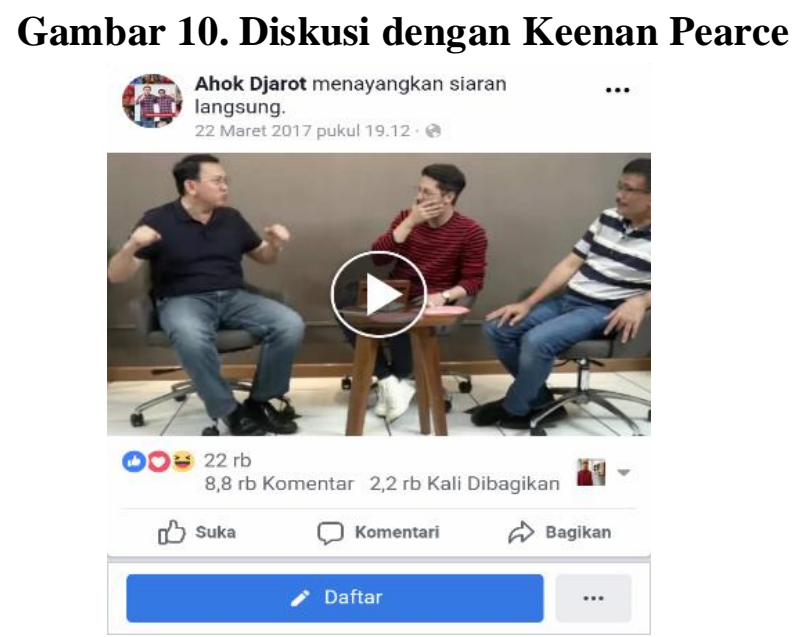

Sumber : https://m.facebook.com/AhokDjarot/

Gambar 10 menunjukkan siaran langsung Ahok-Djarot sehingga masyarakat pengguna facebook dapat menyaksikan siaran tersebut dan bisa memberikan tanggapan di komentar yang telah disediakan sehingga langsung direspon oleh Ahok-Djarot. Pada siaran 
langsung tersebut, Ahok-Djarot melakukan sharing dengan bintang tamu Keenan Pearce yang merupakan artis dan pengusaha muda. Mereka berbincang tentang permasalahan yang terjadi di Jakarta. Dalam kesempatan tersebut, Ahok-Djarot menyampaikan program mereka terutama program anak muda di Jakarta dan menjabarkan visi-misi mereka untuk Jakarta. Dengan mengundang artis dan pengusaha muda, diharapkan strategi terserbut dapat menyasar pemilih dari generasi milenial.

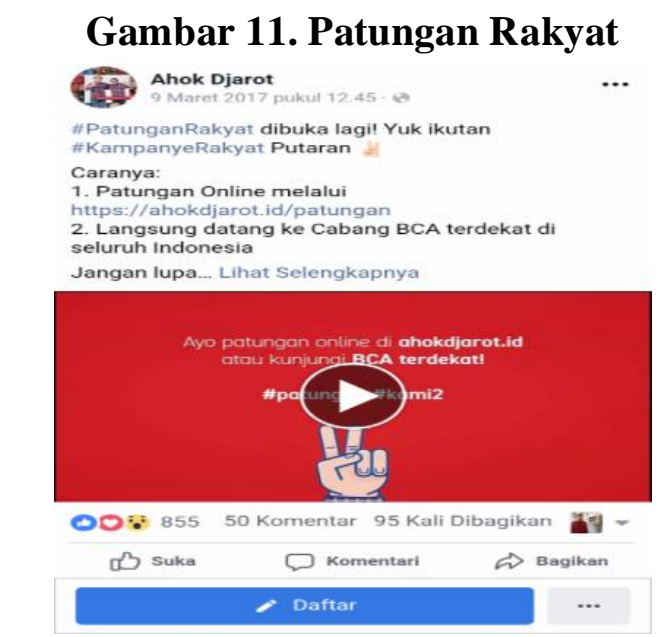

Sumber: https://m.facebook.com/AhokDjarot/

Gambar 11 menunjukkan, bahwa Ahok-Djarot melakukan kampanye kerakyatan yaitu mengadakan gerakan yang diberi nama patungan rakyat yang dilakukan secara online melalui transfer ke bank yang telah disediakan patungan rakyat tersebut bertujuan untuk mengajak masyarakat untuk melakukan patungan yang uang hasil dari patungan tersebut digunakan untuk mendanai kampanye pasangan Ahok-Djarot. Gerakan yang dicanangkan Ahok-Djarot gerakan di medsos yaitu mengajak masyarakat dengan tidak hanya ambil bagian dalam memilih tetapi juga ikut berkontribusi terhadap keberlangsungan Jakarta kedepannya dengan cara ikut patungan rakyat untuk berkampanye membangun Jakarta menjadi lebih yang lebih baik.

\section{2) Anies-Sandi}

Kampanye yang dilakukan oleh pasangan Anies-Sandi di facebook dengan video kreatif disertai dengan teks yang mengajak masyarakat Jakarta untuk memilih pasangan Anies-Sandi. Sehingga kampanye yang dilakukan dengan menggunakan medsos melalui facebook dapat mempengaruhi masyarakat sehingga nantinya mendapatkan suara pemilih untuk memilih pasangan Anies-Sandi. 


\section{Gambar 12. Pilih Nomor 3}

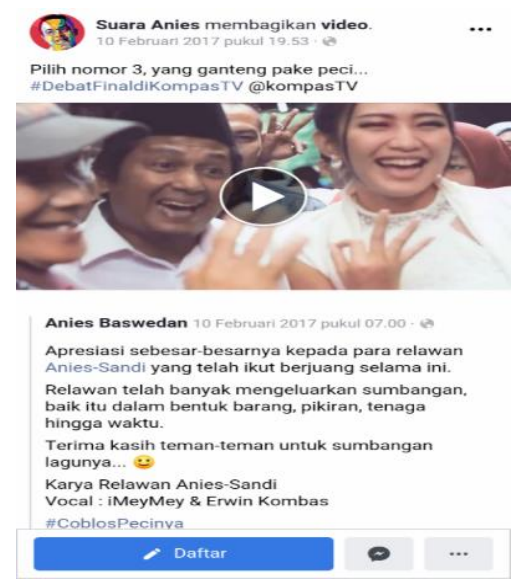

Sumber: https://m.facebook.com/suaraanies/

Gambar 12 menjelaskan tentang video kampanye dengan bernyanyi serta mengajak masyarakat Jakarta mencoblos pasangan nomor urut tiga Anies-Sandi supaya warganya bahagia semua. Pada konten video tersebut pasangan Anies-Sandi menggunakan identitas yaitu dengan mengajak masyarakat Jakarta untuk memilih pasangan Anies-Sandi yaitu dengan menggunakan hak suaranya untuk memilih pada surat suara yang ganteng dengan sebagai sosok muslim yang memakai peci yang menggambarkan diri Anies-Sandi. Pada konten video tersebut juga menjelaskan bahwa sosok Anies-Sandi merupakan sosok yang berpengalaman dan anti korupsi sabagai sosok berbudaya yang memiliki hati.

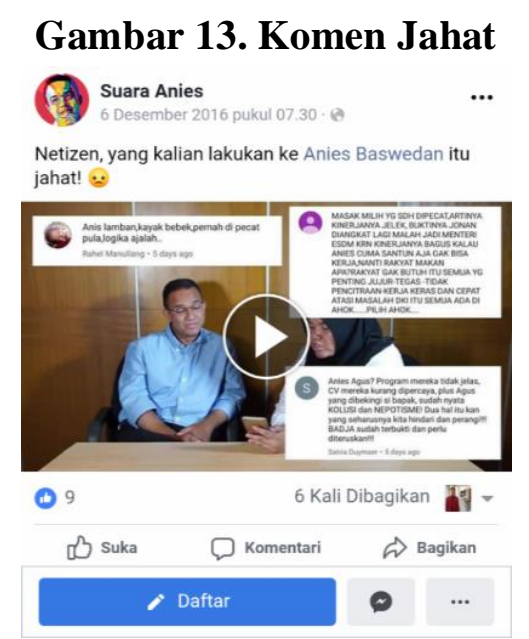

Sumber: https://m.facebook.com/suaraanies/

Pada Gambar 13, terlihat di akun facebook Anies-Sandi ada konten kampanye menarik sebagai hiburan untuk pendukung dan masyarakat yang diberi nama "komen jahat" yang berisikan komentar sindiran dan hujatan dari netizen untuk Anies. Dalam video terserbut, sindiran dibaca langsung oleh seseorang langsung di depan Anies sehingga langsung ditanggapi Anies dengan respon lucu sehingga masyarakat yang melihat konten tersebut dapat terhibur. Video tersebut bertujuan, bahwa Anies adalah seseorang yang sabar dan dapat menerima kritikan dari netizen maupun masyarakat umum. 


\section{Gambar 14. Kampanye Positif Anies}

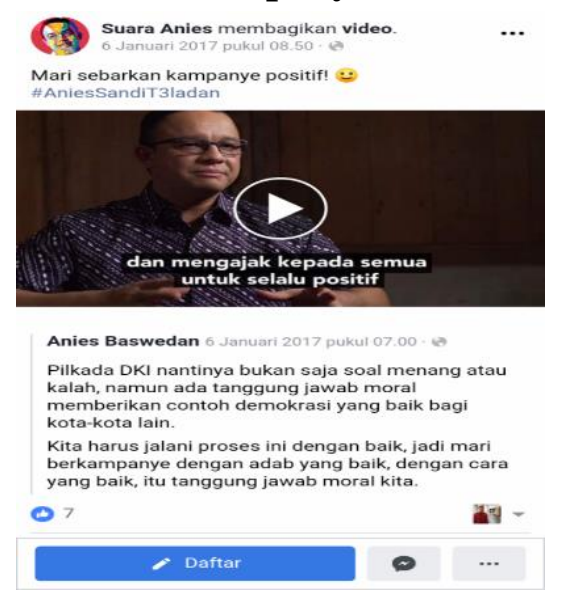

Sumber: https://m.facebook.com/suaraanies/

Pada Gambar 14, Anies-Sandi memberikan pesan positif melalui video dengan mengajak semua masyarakat untuk selalu positif maupun pada saat melakukan kampanye dengan menggunakan hal yang postif pada Pilkada Jakarta 2017 dengan tidak menggunakan isu yang digunakan untuk menyerang lawan politiknya dan tidak menyebarkan berita hoax untuk saling serang. Anies melalui konten video tersebut juga memberikan masukan positif mengenai Pilkada yang berlangsung di Jakarta dengan memberikan pesan yaitu bukan soal menang atau kalah, namun ada tanggung jawab moral dan memberikan contoh demokrasi yang baik bagi kota-kota lain sehingga pelaksanaan Pilkada dapat berlangsung dengan damai, jujur dan adil.

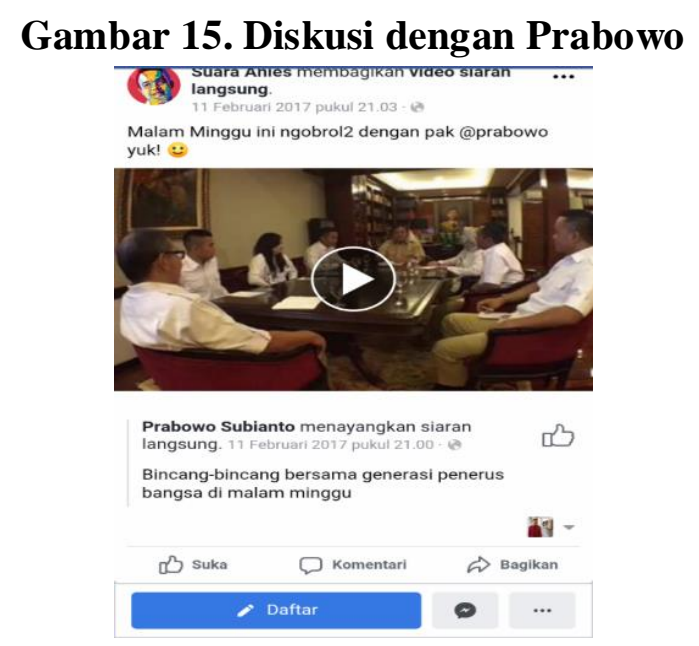

Sumber: https://m.facebook.com/suaraanies/

Seperti pada Gambar 15, Anies-Sandi juga menggunakan fitur siaran langsung di facebook dengan menayangkan kegiatan mereka pada saat berdiskusi dengan ketua umum Gerindra, Prabowo Subianto. Pada diskusi yang disiaran langsung bapak Prabowo Subianto berbagi pengalamannya dengan generasi muda agar menjadi generasi penerus masa depan Indonesia dengan pengalaman dari Prabowo Subianto sebagai tokoh Nasional Indonesia dengan latar belakang sebagai mantan jenderal Kopasus dan pengusaha yang juga sekarang 
menjabat sebagai ketua umum partai Gerindra yang mendukung pasangan Anies-Sandi dengan latar belakang Prabowo yang sangat membanggakan. Maka dengan itu, melalui siaran langsung tersebut prabowo memotivasi dan mengajak generasi muda agar menjadi pribadi yang lebih baik kedepan juga dengan memanfaatkan medsos dengan bijak agar tidak mudah terpengaruhi isu negatif yang beredar di medsos.

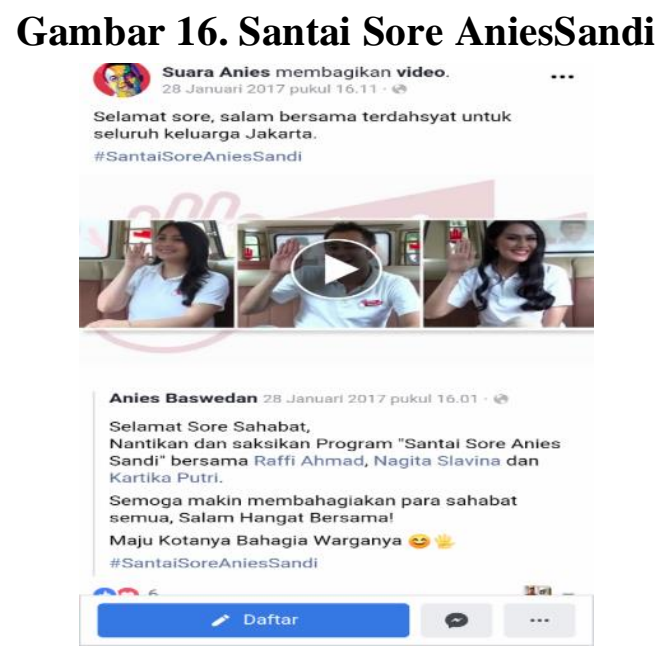

Sumber: https://m.facebook.com/suaraanies/

Pada postingan kampanye di akun facebook, sebagaimana di Gambar 16, tim sukses Anies-Sandi menggandeng artis papan atas Indonesia yaitu Raffi Ahmad, Nagita Slavina, dan Kartika Putri sebagai daya tarik untuk mendapatkan dukungan dari generasi milenial dan masyarakat pengguna sosial media. Pada konten video yang diberi nama santai sore AniesSandi tersebut mereka menjelaskan mengenai pribadi dari Anies-Sandi yang memiliki pribadi yang baik, juga memiliki ide dan gagasan yang oke banget untuk Jakarta. Dan mereka mengajak untuk lebih mengenal sosok Anies-Sandi melalui kampanye dengan membawa mobil yang mengelilingi kota Jakarta dan di dalam mobil tersebut mereka memberikan pertanyaan dari para netizen di medsos yang dijawab langsung oleh AniesSandi sehingga dengan itu para netizen dapat mengenal lebih dekat sosok pribadi AniesSandi.

\section{Partisipasi}

Keikutsertaan dan emosi seseorang dalam memberikan respon terhadap suatu proses serta mendukung pencapaian tujuan dan bertanggung jawab atas keterlibatannya. Partisipasi politik sering kali dihubungkan dengan proses politik yang demokratik, yang melibatkan interaksi perseorangan dan organisasi. Partisipasi politik dihubungkan dengan demokrasi politik yang mengedepankan prinsip perwakilan dan partisipasi tidak langsung.

\section{a. Respon Masyarakat di Medsos}

Medsos berbeda dengan media massa karena sifatnya yang lebih interaktif. Maka dengan itu, masyarakat yang memiliki akun media sosial bisa memberikan respon dengan cara memberikan tanggapan mereka terkait postingan di medsos antara Kubu Ahok dan Anies. 
Mengenai respon masyarakat di medsos, penulis menganalisis frekuensi respon masyarakat melalui facebook sebagai berikut:

Pada postingan akun facebook di kedua kubu terkait dengan pengunaan isu yang diposting di medsos mereka, itu semua memiliki tujuan untuk mempengaruhi pilihan masyarakat pada Pilkada Jakarta 2017. Maka, adanya tanggapan dan interaksi dari masyarakat di facebook seperti like, share, dan comment adalah cara kedua kubu meraih dukungan warga. Frekuensi respon masyarakat terhadap kedua kubu dapat terlihat pada Tabel 3.

Tabel 3. Respon Masyarakat di Facebook

\begin{tabular}{|c|c|c|c|c|c|}
\hline \multirow{2}{*}{ Nama } & Isu & $\begin{array}{c}\text { Jumlah } \\
\text { Postingan }\end{array}$ & Like & Komentar & Share \\
\hline \multirow{2}{*}{$\begin{array}{c}\text { Ahok- } \\
\text { Djarot }\end{array}$} & Pilkada Damai & 8 & 30.500 & 1.641 & 1.758 \\
\cline { 2 - 6 } & Jakarta Punya Semua & 11 & 60.629 & 2.569 & 10.700 \\
\cline { 2 - 6 } & Keadilan Untuk Ahok & 20 & 184.700 & 22.698 & 16.240 \\
\hline \multirow{2}{*}{$\begin{array}{c}\text { Frekuensi } \\
\text { Anies- } \\
\text { Sandi }\end{array}$} & 3 & 39 & 275.829 & 26.908 & 28.698 \\
\cline { 2 - 6 } & Pemimpin muslim & 14 & 59 & 2 & 17 \\
\hline Santun & 3 & 3 & 62 & 18 \\
\hline \multirow{2}{*}{ Frekuensi } & 2 & 17 & 62 & 2 & 18 \\
\hline
\end{tabular}

Sumber: https://m.facebook.com/AhokDjarot/ dan https://m.facebook.com/suaraanies/

\section{1) Ahok-Djarot}

Pada postingan di facebook Ahok-Djarot yaitu pertama untuk isu Pilkada damai untuk jumlah postingan 8 , masyarakat yang menyukai postingan sebanyak 30.500, masyarakat yang memberikan komentar sebanyak 1.641, masyarakat yang membagikan postingan sebanyak 1.758, kedua Jakarta punya semua (keberagaman) untuk jumlah postingan sebanyak 11, masyarakat yang menyukai postingan sebanyak 60.629, masyarakat yang memberikan komentar sebanyak 2.569, masyarakat yang membagikan postingan sebanyak 10.700, ketiga keadilan untuk Ahok untuk jumlah postingan sebanyak 20, masyarakat yang memberikan komentar sebanyak 22.698, masyarakat yang menyukai postingan sebanyak 184.700, masyarakat yang membagikan postingan sebanyak 16.240. Jika di hitung keseluruhan untuk frekuensi isu yang digunakan oleh Ahok-Djarot untuk mempengaruhi masyarakat di akun facebook yaitu berjumlah 3, untuk postingan keseluruhan sebanyak 39, untuk jumlah keseluruhan yang menyukai postingan sebanyak 275.829 , untuk jumlah komentar keseluruhan sebanyak 26.908, dan untuk jumlah keseluruhan yang membagikan postingan sebanyak 28.698. 


\section{2) Anies-Sandi}

Pada postingan di facebook Anies-Sandi yaitu pertama Pemimpin Muslim untuk jumlah postingan 14 , masyarakat yang menyukai postingan sebanyak 59, masyarakat yang memberikan komentar sebanyak 2, masyarakat yang membagikan postingan sebanyak 17, kedua reklamasi pantai untuk jumlah postingan sebanyak 3, masyarakat yang menyukai postingan sebanyak 3 , pada postingan ini tidak ada masyarakat yang memberikan komentar, masyarakat yang membagikan postingan sebanyak 18. jika di hitung keseluruhan untuk frekuensi isu yang digunakan oleh kubu Anies-Sandi untuk mempengaruhi masyarakat pada facebook yaitu 2, untuk jumlah postingan keseluruhan sebanyak 17, untuk jumlah keseluruhan yang menyukai postingan sebanyak 62, untuk jumlah komentar keseluruhan sebanyak 2, dan jumlah keseluruhan yang membagikan postingan sebanyak 18 .

\section{KESIMPULAN}

Politisasi isu pribumi pada Pilgub Jakarta 2017 di medsos yang digunakan oleh kubu Ahok maupun kubu Anies melalui facebook adalah alat kepentingan untuk mempengaruhi masyarakat pada Pilkada Jakarta 2017. Berdasarkan tiga indikator polisisasi isu pribumi, kesimpulannya adalah sebagai berikut.

1. Isu dan kepentingan yang digunakan oleh kedua kubu di medsos bertujuan untuk kepentingan Pilkada Jakarta 2017 sehingga dengan isu yang disebarkan melalui facebook dapat mempengaruhi masyarakat. Pertama, akun facebook Ahok-Djarot menggunakan tiga isu: Pilkada damai, Jakarta punya semua (keberagaman), dan keadilan untuk Ahok yang diposting dari Februari-Mei 2017 dengan jumlah postingan sebanyak 39 kali. Kedua, akun facebook Anies-Sandi menggunakan dua isu: pemimpin Muslim santun dan reklamasi pantai yang diposting dari November 2016-Januari 2017 dengan jumlah postingan sebanyak 18 kali. Jumlah frekuensi isu yang diposting oleh kubu Ahok di facebook lebih banyak dibandingkan dengan kubu Anies. Isu yang diposting oleh akun facebook antara kedua kubu dapat menggiring opini masyarakat yang akan menimbulkan dampak negatif: terjadinya konflik di masyarakat, sehingga mengakibatkan perpecahan karena ada kebencian tertentu terhadap suku, agama, ras dan golongan (SARA).

2. Agenda politik Pilkada Jakarta 2017 adalah berupa opini dalam berita online yang memberitakan isu mengenai SARA yang bisa merubah pandangan masyarakat. Agenda politik kubu Ahok-Djarot di facebook adalah memposting video yang menampilkan warga Jakarta yang memberikan penjelasan kepada masyarakat tentang sosok Ahok yang memiliki sikap tegas, jujur, dan berani agar warga Jakarta tidak ragu memilih Ahok-Djarot. Konten siaran langsung di facebook juga menggaet pemilih muda dengan menghadirkan bintang tamu artis dan pengusaha muda seperti Keenan Pearce. Pada konten tersebut, masyarakat bisa memberikan komentar dan langsung ditanggapi oleh Ahok-Djarot dan terdapat motivasi yang diberikan Ahok-Djarot untuk masyarakat. Kubu Ahok-Djarot juga melakukan kampanye kerakyatan di facebook yang mengajak masyarakat melakukan patungan secara online untuk mendanai kampanye Ahok-Djarot. Sementara kubu AniesSandi memposting konten video bernyanyi untuk mengajak warga Jakarta mencoblos Anies-Sandi. Terdapat video kampanye menarik yaitu komen jahat yang berisi komentar 
hujatan netizen untuk Anies yang langsung dibaca dan direspon oleh Anies secara lucu sehingga masyarakat terhibur saat melihat video tersebut. Anies juga mengajak berkampanye positif di medsos dengan tidak menggunakan isu menyerang lawan politik. pada konten siaran langsung di facebook, kubu Anies melakukan diskusi dengan menghadirkan Prabowo Subianto yang memiliki pengaruh besar dengan memberikan motivasi pada generasi muda agar bijak dalam menggunakan medsos. Kubu Anies juga memanfaatkan sejumlah sebagai tim sukses seperti Raffi Ahmad, Nagita Slafina, dan Kartika Putri agar mendapatkan dukungan generasi milenial.

3. Respon yang dilakukan masyarakat adalah memberikan tanggapan pada postingan akun Facebook kubu Ahok dan kubu Anies. Pertama, respon masyarakat terhadap isu-isu yang ditawarkan di postingan facebook Ahok-Djarot berjumlah 39 kali respon. Ada sebanyak 275.829 like, 26.908 komentar, dan 28.698 kali share. Ini artinya, komentar positif masyarakat cukup banyak terhadap Ahok-Djarot. Kedua, respon masyarakat di postingan facebook Anies-Sandi terhadap isu-isu ditawarkan frekuensinya sebanyak 14 kali, 62 like, 2 komentar, dan 18 kali share. Mayoritas komentar netizen adlaah positif. Dengan demikian, kubu yang paling banyak mendapatkan respon masyarakat di facebook adalah Ahok-Djarot.

Dari ketiga indikator terserbut, indikator yang paling dominan adalah isu dan kepentingan karena melalui statemen yang diposting, kedua kubu memiliki tujuan agar masyarakat dapat terpengaruh dengan cara mempolitisasi ide dan gagasan melalui konten yang diposting di akun facebook kedua kubu terserbut sehingga mereka dapat mempengaruhi suara pemilih dalam rangka memenangkan Pilkada Jakarta 2017.

\section{DAFTAR PUSTAKA}

Ardha, B. (2014). Social media sebagai media kampanye partai politik 2014 di Indonesia. Jurnal Visi Komunikasi, 13(1), 105-120.

Detik.com (2016). Inilah akun media sosial resmi kampanye para paslon Cagub-Cawagub Jakarta. Diambil dari https://news.detik.com/berita/d-3331494/inilah-akun-media-sosialresmi-kampanye-para-paslon-cagub-cawagub-jakarta.

Detik.com (2017). lSI Denny JA: Anies unggul di FB dan Instagram, Ahok di twitter. Diambil dari https://m.detik.com/news/berita/3452697/lsi-denny-ja-anies-unggul-difb-daninstagram-ahok-di-twitter

Detik.com (2017). 132 juta pengguna internet Indonesia, 40\% penggila medsos. Diambil dari: https://inet.detik.com/cyberlife/d-3659956/132-juta-pengguna-internet-indonesia-40penggila-medsos.

Junaidi, A. (2017). Media dan keberagaman: Analisis pemberitaan media daring seputar Pemilihan Kepala Daerah DKI Jakarta. Jurnal Muara Ilmu Sosial, Humaniora, dan Seni,1 (1), 329-337.

Kompas.com (2015). Media sosial penggerak aktif isu publik. Diambil dari : https//nasional.kompas.com/read/2015/10/26/1501007.

Kompas.com (2017). Pribumi dan politik populisme. Diambil dari : 
https://nasional.kompas.com/read/2017/10/17/10321011/pribumi-dan-politikpopulisme\#page1.

Kompas.com (2017). Isu di media sosial pengaruhi warga Jakarta mengubah pilihannya. Diambildari:https://megapolitan.kompas.com/read/2017/02/01/19141361/isu.di.media.so sial.pengaruhi.warga.jakarta.mengubah.pilihannya.

Nazir, M. (2003). Metode penelitian. Jakarta: Ghalia Indonesia.

Ngadino, A (2009). Orang Bangsa Indonesia asli dalam perspektif hukum kewarganegaraan. Jurnal Simbur Cahaya, 38(1), 1-24.

Sipahutar, M. Z. (2018). Politik pribumi dan non pribumi: Analisis wacana kritis identitas Keindonesiaan dalam pidato Anies Baswedan. Medan: Universitas Sumatera Utara.

Tempo.com (2016). Komnas HAM : Hindari isu SARA dalam Pilkada DKI. Diambil dari :https://www.google.com/amp/s/pilkada.tempo.co/amp/820975/komnas-hamhindari-isu-sara-dalam-pilkada-dki.

Tempo.com (2017). Pilkada DKI, Anies-Sandi fokus kampanye di media sosial. Diambil dari :https://pilkada.tempo.co/read/857241/pilkada-dki-anies-sandi-fokus-kampanye-dimedia-sosial

Tajuddin, M.S \& Sani, M. (2016). Berbagai kasus konflik di Indonesia: Dari isu non pribumi, isu agama, hingga isu kesukuan. Jurnal Sulesana, 10, 63-72. 